\section{ASPECTOS PEDAGÓGICOS EM FUNDAMENTOS DE ENFERMAGEM: \\ uma construção participativa}

A presente dissertação constitui-se na descrição e análise dos aspectos pedagógicos no ensino da Disciplina Fundamentos de Enfermagem do Curso de Enfermagem da Universidade Estadual de Londrina, discutidos em um grupo formado a partir das enfermeiras-professoras desta área. $\mathrm{O}$ trabalho coletivo empreendido buscou propiciar ao grupo de professoras reflexões quanto à inquietação em como trabalhar os aspectos pedagógicos, numa construção participativa, visando à melhoria do ensino. Para tanto, utilizou-se a Metodologia da Pesquisa Participante, tendo como referencial teórico-metodológico impulsionador as etapas citadas por HAGUETTE (1987) e as fases para a construção do conhecimento descritas por PRADA (1996). A pesquisa foi desenvolvida em três etapas: 1- fase préprocesso participativo, com a realização de entrevista com as professoras participantes do grupo, para obtenção de informações sobre o saber e fazer didático-pedagógico na Disciplina. Nesta fase levantou-se também dados com os alunos sobre a Disciplina $e$ o desempenho das professoras; 2 - fase do processo participativo com a realização das reuniões do grupo participante, as quais foram gravadas e transcritas; 3- fase pósprocesso participativo, com levantamento dos entendimentos e práticas docentes, decorrentes da vivência no grupo de pesquisa e novo levantamento de dados com os alunos quanto a percepção destes sobre a Disciplina e o desempenho das professoras. Das reflexões e discussões provenientes do processo participativo, que foram alicerçadas no referencial teórico da Pedagogia HistóricoCrítica da Educação, selecionaram-se as concepções e práticas pedagógicas mais relevantes, através da apresentação $e$ discussão das categorias Objetivos, Conteúdos, Metodologia e Avaliação. Todo o trabalho realizado pelo grupo foi registrado $e$ analisado a partir da literatura selecionada dentro da concepção educacional adotada. Constatou-se, pela triangulação dos dados obtidos nas três etapas, que: houve por parte das professoras esforço quanto a assiduidade e participação nas reuniões, conseqüentes do compromisso pessoal assumido com o grupo; as reflexões produzidas no e com o grupo sobre os aspectos pedagógicos repercutiram na concepção e no fazer docente das envolvidas, em grau e maneiras diferenciados; a Avaliação e o Conteúdo foram os aspectos pedagógicos de maior envolvimento $e$ repercussão coletiva na prática do ensino da Disciplina; as vivências positivas e/ou negativas foram importantes para $o$ crescimento $e$ fortalecimento das participantes e do grupo; a tarefa de coordenar um grupo demanda algumas características essenciais para o bom 
desempenho do pesquisador-organizador; as dificuldades e contradições experimentadas durante o processo participativo demonstraram que na heterogeneidade de idéias e/ou ações também se constrói e aprende. Finalmente, concluiu-se que o processo coletivo deve ser contínuo para o aperfeiçoamento pedagógico dos professores, eternos aprendizes do ensinar a aprender, agentes educativos preocupados com a formação de futuros enfermeiros críticos $e$ transformadores da realidade.

Maria Helena Dantas de Menezes Guariente Tese de Mestrado, 1997 Orientadora: Prof ${ }^{a}$ Dra Neusi Aparecida N. Berbel Faculdade de Educação/UEL

\section{EDUCAÇÃO MÉDICA E SAÚDE: limites e possibilidades das propostas de mudança}

Este estudo insere-se no campo de desenvolvimento de recursos humanos em saúde e neste está orientado para o componente formação, centrando-se particularmente na educação médica. Tendo como cenário a América Latina, região em que se desenvolvem desde os anos 80 processos nacionais de reforma do setor saúde, realizou-se uma análise acerca do papel que os recursos humanos desempenham nestes processos. Foi constatada a existência de preocupações quanto à importância dos recursos humanos em saúde na construção de novos modelos de atenção à saúde mas, paradoxalmente, verificou-se a inexistência de políticas voltadas à reorientação dos perfis profissionais. A partir de uma reconstrução histórica do movimento latino-americano de educação médica e de suas relações com a educação médica norte-americana, analisaram-se os embasamentos teóricoconceituais, os atores e os impactos das iniciativas que ocorreram na segunda metade deste século, desde a medicina preventiva (anos 50/60) até a integração docenteassistencial (anos 70/80). Ao mesmo tempo, incorporaram-se na análise os acontecimentos mundiais de educação médica que ocorreram no final dos anos 80 e início dos anos 90, buscando identificar suas relações com o movimento regional. Essa análise permitiu identificar as bases $e$ motivos do surgimento, nos anos 90, de quatro propostas de mudança da educação médica que vêm tendo lugar nos países da América Latina: "a proposta UNI" (Uma nova iniciativa na educação dos profissionais de saúde: união com a comunidade), da Fundação Kellogg; a "proposta Changing" (Mudando a educação e a prática médica: uma agenda para a ação), da OMS; a “proposta Network”, da Rede de instituições educacionais de ciências da saúde orientadas para a comunidade; a "proposta Gestão de 